\title{
Comparative Analysis on Shariah Governance in Malaysia: SGF 2010, IFSA 2013 and SGPD 2019
}

Muhammad Iqmal Hisham Kamaruddin (Corresponding author)

Faculty of Economics and Muamalat, Universiti Sains Islam Malaysia

Nilai, Negeri Sembilan, Malaysia

E-mail: m.iqmalhisham@gmail.com

Mustafa Mohd Hanefah

Faculty of Economics and Muamalat, Universiti Sains Islam Malaysia

Nilai, Negeri Sembilan, Malaysia

E-mail: mustafa@usim.edu.my

Zurina Shafii

Faculty of Economics and Muamalat, Universiti Sains Islam Malaysia

Nilai, Negeri Sembilan, Malaysia

E-mail: anakshafii@yahoo.com

Supiah Salleh

Faculty of Economics and Muamalat, Universiti Sains Islam Malaysia

Nilai, Negeri Sembilan, Malaysia

E-mail: chuyah@usim.edu.my

Nurazalia Zakaria

Faculty of Economics and Muamalat, Universiti Sains Islam Malaysia

Nilai, Negeri Sembilan, Malaysia

E-mail: nurazalia@usim.edu.my 
Received: Dec. 29, 2019 Accepted: Jan. 25, 2020 Online published: Feb. 10, 2020

doi:10.5296/jpag.v10i1.16157

URL: https://doi.org/10.5296/jpag.v10i1.16157

\begin{abstract}
The main focus of shariah governance for an organization is to ensure that it is comply with shariah laws and regulations. Under Islamic finance industry, shariah governance is being given attention due to rapid growth of this industry in the world. For Malaysia, the authority through Bank Negara Malaysia (BNM) have taken a proactive role by introducing shariah governance guidelines including the Shariah Governance Framework (SGF) 2010, the Islamic Financial Services Act (IFSA) 2013 and the latest is the Shariah Governance Policy Document (SGPD) 2019. These shariah governance guidelines are supposed to support the development of shariah governance practices especially by Islamic Financial Institutions (IFIs) in Malaysia. However, there is limited to none study conducted to compare these guidelines. These shariah governance guidelines is necessary to be compared in order to find out whether these guidelines are complemented each other and to identify any differences among these guidelines. Therefore, the aim of this study is to compare between these shariah governance guidelines. Based on the analysis, it has been found that SGPD 2019 is the most comprehensive covers on shariah governance as compared to IFSA 2013 and SGF 2010. However, these three guidelines still not become comprehensive enough, as there is still limited to none discussion on the definition and objectives of shariah governance itself.
\end{abstract}

Keywords: Shariah governance, SGF 2010, IFSA 2013, SGPD 2019

\title{
1. Introduction
}

The emergence of shariah governance, especially in Islamic financial institutions (IFIs) is consistent with the requirements of maqasid shariah. Ibn 'Ashur defined maqasid shariah as the meaning and secrets that can be understood from shariah perspectives as part of the shariah process (Abdul Rahman, 2015). In general, maqasid shariah is classified into three categories, which are: (i) necessities (dharuriyyat); (ii) conveniences (hajiyyat); and (iii) refinements (tahsiniyyat). Under dharuriyyat, it consists of five elements including religion (ad-din), life (an-nafs), mind (al-aqal), descendent (an-nas) and wealth (al-mal).

Abozaid and Dusuki (2007) posit that to realize the true meaning of maqasid shariah, IFIs must make sure that all its transactions are Shariah compliant, not limited to legal technicalities and forms but also on the economic substance that is based on the objectives outlined by shariah. Furthermore, Shafii et al. (2010) states that the development of shariah governance is important for determining the procedures (maqasid shariah) for each of the Islamic products and services provided by IFIs. Thus, it can be said that shariah governance in IFIs is important as to achieve financial and economic stability.

Due to the rapid developments in Islamic finance and banking, it can be contended that the developments and actual practice of shariah governance in Malaysia are at a crossroads. It means that Malaysian stakeholders have to make important decisions and choices with regard 
to compliance and performance of public listed Islamic banks. Nevertheless, the potential of Islamic finance cannot be underrated. First, Malaysia can be considered ahead in Islamic finance industry (Khan \& Bhatti, 2008; Ibrahim, 2009; Khiyar, 2012). According to the Islamic Finance Country Index (IFCI) by the Global Islamic Finance Report 2016, Malaysia holds the first place at the first time it was introduced (GIFR, 2016). In addition, the World Islamic Banking Competitiveness Report 2016 also highlights the fact that from US\$920 billion of total Islamic finance asset reported in 2015, Malaysia has taken the second place in the global Islamic finance industry with 17 per cent contribution in Islamic financial assets and 15.5 per cent controlling in the global Islamic finance market share (Ernst\&Young, 2016). Furthermore, Malaysia is the world's biggest sukuk market, constituting about 67 per cent of the global outstanding sukuk (CIBAFI et al., 2015). However, despite the huge achievement gained by Malaysia in the Islamic finance industry globally, market share is only found to comprise only 21.3 per cent of the total banks' market share in Malaysia.

Secondly, we observed significant positive developments by Bank Negara Malaysia (BNM) as a regulatory body by introducing the Shariah Governance Framework (SGF) in 2010. SGF has managed to strengthen shariah governance practices in IFIs. The objective of SGF was to ensure good shariah practices in IFIs. Besides, BNM also took an initiative by issuing the Islamic Financial Services Act (IFSA) in 2013. This shows that BNM's efforts in strengthening shariah governance practices in IFIs are ongoing. In September 2019, BNM issued the Shariah Governance Policy Document (SGPD) after having issued an ED in 2017. The SGPD tightens the role of the board, management and the shariah committee (SC). The SC in comparison is the guardian for ensuring that products and instruments adhere to shariah principles. Under the latest SGPD, the SC has to bear more responsibility as compared to SGF. This indicates the utmost importance of shariah governance placed by the regulator on IFIs.

Third, it is also observed that there are an increasing number of international and national level conferences, seminars and workshop programs to deliberate issues related to shariah governance in IFIs (Hanefah \& Kamaruddin, 2019). These programs involve not only academia, but also experts in shariah governance who are interested in the issues. Moreover, these conferences and programs have helped to enhance societal awareness and understanding on shariah governance and assurance as well as to put this agenda on a higher pedestal over the past few years.

Last but not least, there have been a number of unresolved concerns and challenges in the area of shariah governance especially among the IFIs. This includes the centralization or decentralization of the shariah body in IFIs, the competence of shariah scholars and practitioners in IFIs, the availability of adequate shariah scholars and practitioners in IFIs and the capabilities of IFIs in carrying all shariah functions (Abdul Rahman, 2010; Kamaruddin \& Hanefah, 2017; Shafii et al. 2013). Many of these issues and challenges refer mainly to the need for competent shariah scholars and practitioners such as shariah auditors and shariah officers that are currently insufficient in the country.

A comparative analysis between shariah governance framework (SGF) 2010, IFSA 2013 and 
SGPD 2019 is discussed in this paper. It begins with an overview of shariah governance including characteristics and limitations of shariah governance practices. Then, this paper continues with discussions on SGF 2010, IFSA 2013 and SGPD 2019. Impact on Islamic finance is then discussed. Lastly, this paper concludes with several recommendations for the regulators and the industry.

\section{Overview of Shariah Governance}

Shariah governance is about the relationship between organizations and its stakeholders, which include employees, creditors, government, society and others. Shariah governance is different from conventional corporate governance whereby it also considers shariah law or maqasid shariah in its relationship. These relationships are solely used to determine and control the strategic direction and performance of the Islamic banks.

As shariah governance differs in several aspects in comparison to corporate governance, it is crucial for us to understand these differences. First, in terms of the definition, there is a similar agreement between the definition of corporate governance and shariah governance. For corporate governance, the worldwide acceptable definition on corporate governance is the Cadbury Report 1992, which defines corporate governance as:

The system by which companies are directed and controlled. Board of Directors (BOD) is responsible for the governance of their companies. The shareholders' role in governance is to appoint the directors and the auditors and to satisfy themselves that an appropriate structure is in place (Cadbury, 1992).

Meanwhile, for Malaysia, Malaysian Code of Corporate Governance (MCCG) 2017 issued by the Securities Commission of Malaysia defines corporate governance as:

The process and structure used to direct and manage the business and affairs of the company towards enhancing business prosperity and corporate accountability with the ultimate objective of realizing long-term shareholder value, whilst taking into account the interests of other stakeholders (SC, 2017).

For corporate governance in financial institutions, the term of corporate governance for financial institutions has been specifically identified by BNM in the Guideline on Corporate Governance for Licensed Institutions 2013 as:

Involves the manner in which the business and affairs of the individual banking institutions are being governed by their BOD and senior management, how the economic returns are generated to the owners, the day-to-day running of the operations of the business and the consideration of the interests of recognized stakeholders including depositors; and how they behave in a safe and sound manner, in compliance with applicable laws and regulations (BNM, 2013a).

In contrast, for shariah governance definition, at present there is yet to have a common understanding on the general definition on shariah governance. Literatures also show that most of shariah governance studies are in financial sectors (Abdullah Saif Alnasser \& Muhammed, 2012; Hanefah \& Kamaruddin, 2019; Hasan, 2009; Miskam \& Nasrul, 2013). 
However, the definition of shariah governance for IFIs is defined by IFSB-10 of the Islamic Financial Services Board (IFSB): Guiding Principles on Shari'ah Governance Systems for Institutions Offering Islamic Financial Services, as the following:

Set of the strategic roles and functions of each organ of governance and mechanisms for balancing the institutions that offering Islamic financial services accountabilities to various stakeholders (IFSB, 2009).

Second, in terms of the objective, basically the objective of corporate governance is about decision making by whom and for whom that can be viewed in three alternative views, which are: (i) the legal view; (ii) the economic view; and (iii) the accounting view (Lewis, 2005). From legal view perspective, an organization is separate entity that is owned by the shareholders as capital provider, directors as stewardship of the organizations' capital and employees as manager to conduct the operation of the organization using the power delegated to them by the directors. Meanwhile, from an economic view, corporate governance can be viewed as separation between ownership and management of organization in decision making. Thus, corporate governance will ensure agency problems can be solved when shareholders as owner can secure their rights and investments while managers can carry-out their duties and compensated fairly based on their achievements in managing the organization without reducing the interest of shareholders in their decision-making. On the other hand, from an accounting view, corporate governance can be viewed as an accountability and transparency of management toward shareholders as owner and other related interest stakeholders such as employees, creditors, debtors, government and society. These accountability and transparency can be achieved with proper record keeping and disclosure management practices by management according to guidelines and standards given.

Meanwhile, for shariah governance, Nathan Garas and Pierce (2010) attempts to identify the objective of shariah governance from five important resources, which are: (i) religious; (ii) social; (iii) economic; (iv) legal; and (v) governance. Under the religious resources, shariah governance concerns on the capability of the shariah committee in understanding and interpreting shariah principles. Meanwhile, under social resources, shariah governance focused to gain stakeholders' confidence on the transactions and activities conducted by the organization. On the other hand, under economic resources, shariah governance stressed on the performance of the shariah committee as it will effect on the profitability of the organization. While, under legal resources, shariah governance ensure that all related regulators frameworks and guidelines are to be imposed by the organization. Last but not least, under the governance resources, the hierarchical position of the shariah committee gives power for them to set and monitor shariah compliant within the organization.

In other words, the objective of shariah governance is to enhance the role of the BOD, the shariah committee and the management of an organization to execute the shariah compliance and aimed to operate as shariah required (BNM, 2010). Based on this objective, IFSB highlighted four structures and processes that are crucial in shariah governance as documented in IFSB-10, which are:

1. Issue relevant shariah resolutions; 
2. Deployment of such shariah resolutions to operation personnel who monitor daily shariah compliance;

3. Verification of shariah compliance by internal shariah compliance review/audit;

4. Findings on verification of shariah compliance have been noted by the shariah committee.

Third, in terms of the good corporate governance practices, the Organization for Economic Cooperation and Development (OECD, 2014) identified four main components for good corporate governance practices to secure the interests of the shareholders as owners of the organization which are:

1. An active BOD.

2. Imposing the duality role between the Chairman and the Chief Executive Officer (CEO).

3. Outside or non-executive directors as majority of the BOD.

4. Two-tier board (using supervisory boards to supervise BOD).

There are several verses in Quran that encourage Muslims to have good corporate and shariah governance practices. This includes a story of Dzulqarnain, a ruler who followed the righteous path to rule a kingdom. His story is depicted in the following:

Indeed We established him upon the earth, and We gave him to everything a way. So he followed a way (Al-Kahfi 18:84-85).

Corporate governance in Islam is also related with justice and on how to manage an organization according to shariah laws. This had been stated in the following Quranic verses:

Allah commands you to render trusts to whom they are due and when you judge between people to judge with justice. Excellent is that which Allah instructs you. Indeed, Allah is ever Hearing and Seeing (An-Nisa' 4:48).

And We made from among them leaders guiding by Our command when they were patient and [when] they were certain of Our signs (As-Sadjah 32:24).

Chapra and Ahmed (2002) have identified 12 main elements regarding good shariah governance practices for IFIs which are: (i) BOD; (ii) non-executive directors; (iii) executive directors; (iv) senior management; (v) employees; (iv) shariah board; (vii) auditors; (viii) accountability and controls; (x) compensation policies; (xi) board meetings; (xii) annual report, information disclosure and transparency; and (xiii) code of ethics. These elements are closely similar to the good practices that have been suggested for conventional corporate governance.

Thus, it can be concluded that corporate governance and shariah governance have similar definitions, objectives and good practices and conduct. In addition to that, shariah governance requires compliance to shariah which is not required in a normal corporate governance framework. 


\subsection{Shariah Governance Framework (SGF 2010)}

The SGF 2010 issued by BNM in 22 October 2010 sets out the shariah governance process for the IFIs in Malaysia. It issued with the objective to enhance the role of the BOD, the SC and the management of IFIs especially on shariah matters. Besides, this guideline also covers relevant key organs with the responsibility to execute the shariah compliance. Specifically, the SGF 2010 (BNM, 2010) covers:

1. Expectations on IFI's shariah governance structures, processes and arrangements;

2. Guidance for the BOD, the SC and the management of the IFI on shariah matters; and

3. Functions of shariah review, shariah audit, shariah risk management and shariah research.

Generally, the framework is discussed in six sections related to: (i) general requirements of shariah governance; (ii) oversight, accountability and responsibility; (iii) independence; (iv) competency; (v) confidentiality and consistency; and (vi) shariah compliance and research function. First, under the general requirement of shariah governance, IFIs are responsible to establish shariah governance with the comprehensive roles of key organ functions (BNM, 2010). In this section, SGF 2010 highlights that three key organs in shariah governance are the BOD, the SC and the management. Besides, there are also four shariah functions, consist of shariah review, shariah audit, shariah risk management and shariah research. The following Figure 1 illustrates shariah governance model structure that highlight on the roles, functions and reporting relationships for these key organs in IFIs.

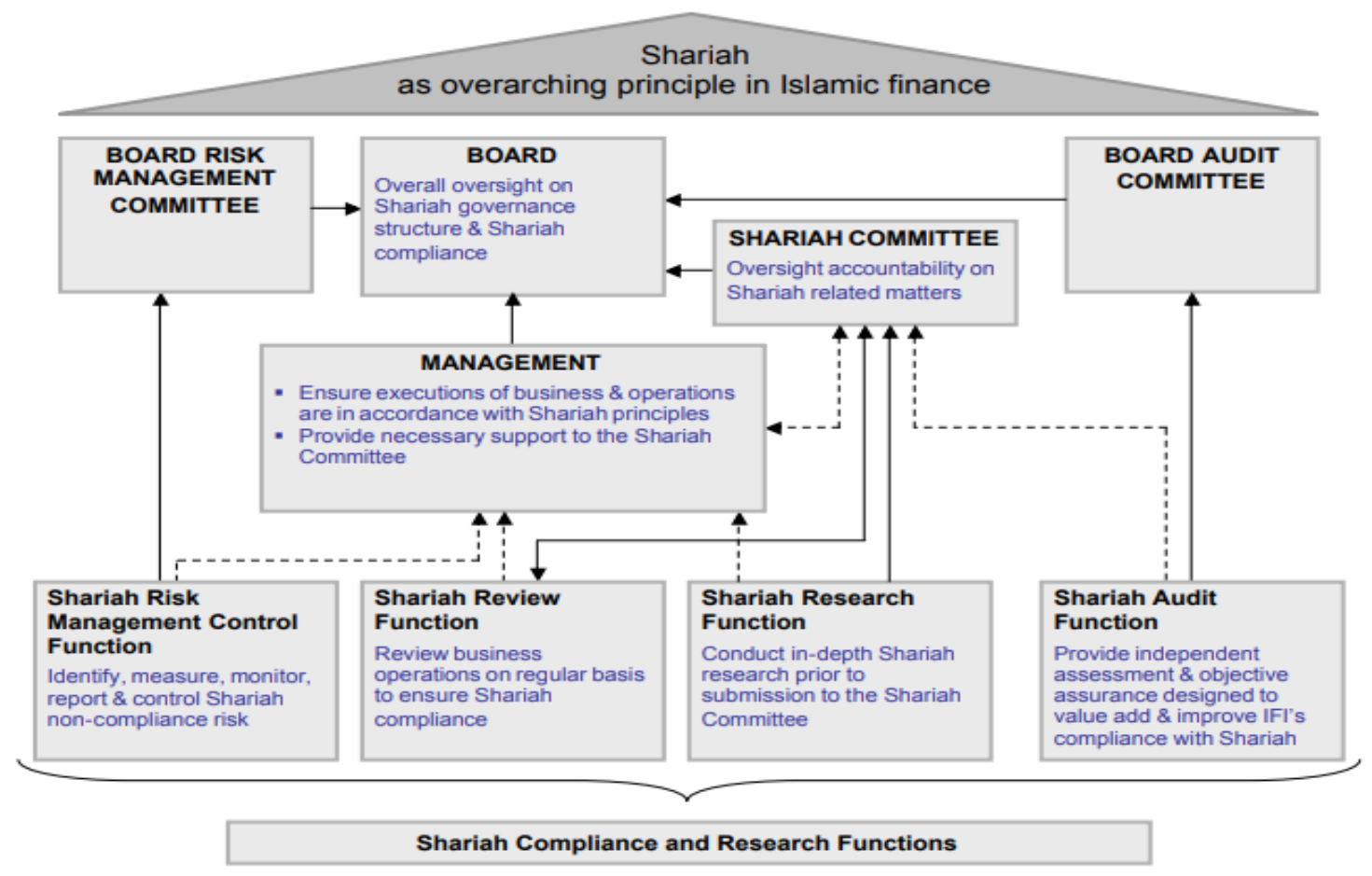

Figure 1. SGF Model for IFIs

Source: BNM (2010) 
Second, under the oversight, accountability and responsibility, IFIs are required to follow strictly the SGF to ensure full compliance. In this section, duties and responsibilities for all three key organs are explained in details. Besides, SGF 2010 also has provided some additional guidelines on duties, responsibilities and accountability of the SC. The details are as in Table 1.

Table 1. Duties, Responsibilities and Accountability of the SC

\begin{tabular}{|l|l|}
\hline Duties \& Responsibilities & Explanations \\
\hline $\begin{array}{l}\text { Responsibility and } \\
\text { accountability }\end{array}$ & $\begin{array}{l}\text { To responsible and accountable for all shariah decisions, } \\
\text { opinions and views. }\end{array}$ \\
\hline $\begin{array}{l}\text { Advise to the BOD and } \\
\text { IFI }\end{array}$ & $\begin{array}{l}\text { To advise the BOD and provide input to the IFI on shariah } \\
\text { matters. }\end{array}$ \\
\hline $\begin{array}{l}\text { Endorse shariah policies } \\
\text { and procedures }\end{array}$ & $\begin{array}{l}\text { To endorse and ensure that shariah policies and procedures are } \\
\text { in line with shariah }\end{array}$ \\
\hline $\begin{array}{l}\text { Endorse and validate } \\
\text { relevant documentations }\end{array}$ & $\begin{array}{l}\text { To ensure that IFI's products and services are comply with } \\
\text { shariah principles. }\end{array}$ \\
\hline $\begin{array}{l}\text { Assess the work of } \\
\text { shariah review and } \\
\text { shariah audit }\end{array}$ & $\begin{array}{l}\text { To assess the work of shariah review and shariah audit to ensure } \\
\text { the compliance with shariah by IFI. }\end{array}$ \\
\hline $\begin{array}{l}\text { Assist related parties on } \\
\text { shariah matters }\end{array}$ & $\begin{array}{l}\text { To assist related parties such as legal counsel, auditor or } \\
\text { consultant that seek for advice on shariah matters. }\end{array}$ \\
\hline $\begin{array}{l}\text { Advise on matters to be } \\
\text { referred to the SAC } \\
\text { opinions }\end{array}$ & $\begin{array}{l}\text { To advise IFI to consult with the Shariah Advisory Council } \\
\text { (SAC) of BNM on shariah matters that could not be resolved. }\end{array}$ \\
\hline $\begin{array}{l}\text { To provide written shariah opinions for IFI to engage with the } \\
\text { SAC or BNM on shariah matters. }\end{array}$ \\
\hline
\end{tabular}

Source: BNM (2010)

Third, under independence, the SC must be observed on their independence to ensure that they can exercise their duties with objective and informed judgment. In this case, the BOD is required to ensure the independence of the SC to ensure the sound shariah decision-making (Kasim et al., 2013). Regarding organizational structure, the independence of the SC is reflected by their position which is at the same level as the BOD. In other words, any decisions made by the SC could not be overruled by the BOD (Hasan, 2009). The BOD has to ensure that IFI implement the decisions made by the $\mathrm{SC}$ and ensure the decisions made are 
not modified without their consent.

Fourth, under competency, all IFI's key organs and functions in shariah governance must have necessary competency based on their responsibilities. Besides, they are also need to enhance their knowledge on shariah on continuous basis and update themselves on the latest developments in Islamic finance. For the SC composition, the majority of the SC members should have a qualification in shariah which includes the study in usul fiqh (Islamic jurisprudence) or fiqh muamalat (Islamic transaction). Besides, IFIs should have a proper process on how to assess the performance of the SC members and also developing suitable succession planning program for the SC.

Fifth, under confidentiality and consistency, the SC must ensure that any information obtained by them in delivering their duties must be treated as confidential and not be misused. Furthermore, this section also stresses that the SC members must maintain their professional ethics, judgment and consistency in ensuring shariah compliance.

Last but not least, under shariah compliance and research function, the framework suggests that IFI must ensure that all its shariah functions, consisting of shariah review, shariah audit, shariah risk management and shariah research must in a good and sound condition. Functions of these four shariah functions in IFIs are summarized in Table 2.

Table 2. Functions of Four Shariah Compliance Functions by SGF 2010

\begin{tabular}{|l|l|}
\hline $\begin{array}{l}\text { Shariah } \\
\text { Functiance }\end{array}$ & Functions \\
\hline $\begin{array}{l}\text { Shariah } \\
\text { Review }\end{array}$ & $\begin{array}{l}\text { Regular assessments on shariah compliance in the activities and } \\
\text { operations. }\end{array}$ \\
- $\quad \begin{array}{l}\text { Examine and evaluate the level of shariah compliance. } \\
\text { - Identify corrective measures to resolve shariah non-compliance. }\end{array}$ \\
$\begin{array}{l}\text { - Propose a sound control mechanism to avoid recurrences of shariah } \\
\text { non-compliance. } \\
\text { - Covers IFI's overall business operations including end-to-end product } \\
\text { development process from product structuring to product offering. }\end{array}$ \\
\hline $\begin{array}{l}\text { Shariah Audit } \\
\text { independent assessment and objective assurance designed to assess its value } \\
\text { and improves the degree of compliance in relation to the IFI's business } \\
\text { operation. } \\
\text { - Covers overall IFI's business operation, including: (i) audit of financial } \\
\text { statement; (ii) compliance audit on organizational structure, people, process } \\
\text { and information technology application system; and (iii) review of adequacy }\end{array}$ \\
\hline
\end{tabular}




\begin{tabular}{|c|c|}
\hline & of the shariah governance process. \\
\hline $\begin{array}{l}\text { Shariah Risk } \\
\text { Management }\end{array}$ & $\begin{array}{l}\text { - Identify, measure, monitor and control of shariah non-compliance risks } \\
\text { to mitigate any possible of shariah non-compliance events. } \\
\text { - Formulate and recommend shariah non-compliance risk management } \\
\text { policies, procedures and guidelines. } \\
\text { - Develop and implement shariah non-compliance risk awareness } \\
\text { processes. }\end{array}$ \\
\hline $\begin{array}{l}\text { Shariah } \\
\text { Research }\end{array}$ & $\begin{array}{l}\text { - Conduct pre-product approval process, research, vetting of issues for } \\
\text { submission and undertake administrative and secretarial matters relating to } \\
\text { the SC. } \\
\text { - Perform in-depth research and studies on shariah issues, day to day } \\
\text { shariah advice and consultancy to relevant parties including product } \\
\text { development. }\end{array}$ \\
\hline
\end{tabular}

Source: BNM (2010)

\subsection{Islamic Financial Services Act (IFSA 2013)}

The IFSA 2013 issued by BNM on 22 March 2013 is enacted to provide the regulations and supervision for IFIs, payment systems, regulatory objectives as well as power and functions of the bank and other relevant aspects related to Islamic finance in Malaysia. Shariah governance becomes one of the important aspects in IFSA, which is stated in Part IV Division II of the statute.

The main objective of IFSA as stated in Section 6 is to promote financial stability and shariah compliance. To achieve this objective, the IFIs under the supervision of BNM must ensure the safety and soundness of their operations, and that their businesses are carried out fairly, responsibly and professionally, as well to ensure that the customers' rights are protected. Whilst observing the above, the IFIs shall also to ensure that their operations are complying with shariah principles (BNM, 2013b).

Under Part IV - Division II on shariah governance, Section 31 stated that for the establishment of the SC, IFIs are needed to apply such establishment directly to BNM. This will ensure BNM to have direct and adequate information on the SC members in IFIs. At the same time, BNM also can have a proper supervision on the SC's duties and activities in IFIs (Miskam \& Nasrul, 2013).

Section 31 of IFSA touches on the appointment of the SC members. This section requires that each SC member must meet the requirements as stated in Section 29(2)(a)(ii) - only those who are really fit and qualified can be appointed as the SC members. Besides, each SC member appointed must get approval from the BNM. This will ensure that all SC members are capable to play their important roles to ensure that IFIs' operation is complied with 
shariah principles.

The following Section 32 requires that the SC must set out their duties and functions as stated in Section 29(2)(a)(i) - including functions and duties of the BOD, senior officers and the SC members in relation to compliance with shariah. This section extends the scope of shariah governance as one of the integral parts in IFIs and the SC shall not be treated only as part or division of IFIs (Miskam \& Nasrul, 2013).

On the other hand, Sections 33 and 34 enables BNM to continuously be updated by IFIs on their SC members. This provision sets out the clause on cessation of the SC members including situations where they can be disqualified from the post. This is to ensure that only those who are qualified can be maintained as the SC members.

Meanwhile, Section 35 instructs the management to provide necessary information to the SC for them to exercise their roles and duties. In this case, the management need to provide any document or information within its or his knowledge, or capable of being obtained by it or him, which the SC may require and ensure that such document or information provided is accurate, complete, not false or misleading in any material particular.

Last but not least, Section 36 requires the SC members to maintain the duty of confidentiality in discharging their duties and functions. Besides, the SC members also are guaranteed with the protection that prevents IFIs from taking any legal action on them if they can prove that they are conducting their duties in good faith.

\subsection{Shariah Governance Policy Document (SGPD 2019)}

The SGPD 2019 issued by BNM on 19 September 2019 strengthened the oversight accountabilities of the BOD, the SC and other key organs who are involved in the implementation of shariah governance. Besides, this policy document also relates to the SC's objective to achieve an effective management on shariah non-compliance risks by strengthening their decision-making process and internal control functions. By implementing SGPD 2019, it is expected for IFIs to have a better arrangement in supporting a strong shariah compliance risk culture. This is based on more active roles from the BOD, the SC and senior management.

Generally, there are six main parts highlighted in SGPD 2019, covering: (i) the BOD; (ii) SC; (iii) senior management; (iv) control functions; (v) shariah compliance culture and remuneration; and (vi) transparency and disclosures. First, under the BOD responsibilities, it emphasizes the importance of interaction between the BOD and the SC. Among the BOD responsibilities include approving policies related to the effective implementation of shariah governance, oversee implementation of the SAC rulings and SC advice, oversee implementation of internal control and any rectification measures on shariah non-compliance, supervise the performance of the senior management in implementing shariah governance and promoting a sound corporate culture adhering to shariah. In addition, the BOD members itself is also required to continuously update themselves with Islamic finance knowledge. 


\section{Ml Macrothink}

For interaction with the SC, the BOD is required to have due regards on SC decisions and advice, ensure that the $\mathrm{SC}$ is free from undue influence by taking necessary actions, establish written policy to identify, assess and manage conflict of interest of the SC, establish effective communication with the SC, allocate sufficient resources for the SC to continuously develop their skills and expertise, establish the proper performance and effectiveness assessment in order to assess the SC and approve remuneration policy that commensurate the SC.

Second, SGPD spells out the responsibilities of the SC, SC meetings, appointment, cessation and disqualification of the SC, SC composition and secretariat to the SC. Among the SC responsibilities include provides an outline that stressed on their mandate, responsibilities and procedures, provide objective and sound advice to the IFIs, responsible for every decisions and advice made, develop a comprehensive procedures to guide its decision-making process, immediately update the BOD on shariah issues, requests for a ruling or advice from the SAC or advice and submit SC decisions and advices to the BNM. Besides, responsibilities of the individual SC members are to exercise objectivity and free from conflict of interest, allocate adequate time for preparation and for attending the SC meetings, ensure consistency in providing their views and not contradict with the SAC and SC rulings, inform on the nature and extent of his or her conflict of interest with the IFI and constantly learns to understand the IFIs' business and operations.

For SC meetings, the Chairman of the $\mathrm{SC}$ is responsible to ensure the $\mathrm{SC}$ meetings are effectively functions. Besides, the SC meetings required to be conducted at least once in every two (2) months. Moreover, IFIs also need to ensure that the presence of each the SC members in the SC meetings for each financial year must not below than $75 \%$, non-physical presence in the SC meetings by the SC members must not become the norm and provide information on the number and attendance of the SC meetings held during the year in the IFI's annual report. Furthermore, IFIs also needs to ensure that minutes of the SC meetings must be maintained, each of the SC meetings must be attended by a majority of shariah qualified members, decisions made by the SC must be based on simple majority agreement, provide the SC with adequate and sufficient information and such information is accurate, comprehensive and clear. In addition, the BOD or senior management is also required to provide useful insights on any business, technical or operational matters during the SC meetings and any matter that gives conflict of interest, the particular SC member is restrained to involve and voting in that particular discussion.

For appointment, cessation and disqualification of the SC, there are several requirements need to be met in order to become a SC member. The criteria for SC member are detailed in the following Table 3 . 
Table 3. Appointment, Cessation and Disqualification of the SC Member

\begin{tabular}{|c|c|}
\hline $\begin{array}{l}\text { Shariah } \\
\text { Compliance } \\
\text { Function }\end{array}$ & Criteria \\
\hline Appointment & $\begin{array}{l}\text { - Muslim individual; } \\
\text { - Fulfill all requirements as stated in the Fit and Proper Criteria; and } \\
\text { - Shariah qualified or an expert with relevant skills, knowledge and } \\
\text { experience required by the SC. }\end{array}$ \\
\hline $\begin{array}{l}\text { Shariah } \\
\text { Qualified Person }\end{array}$ & $\begin{array}{l}\text { - Minimum a bachelor degree in shariah (includes usul fiqh or fiqh } \\
\text { muamalat); } \\
\text { - Have solid knowledge in shariah with sound Islamic finance } \\
\text { knowledge and experience; and } \\
\text { - Have strong proficiency and knowledge in Arabic (written and } \\
\text { verbal), with good command in the IFI's preferred language. }\end{array}$ \\
\hline Disqualification & $\begin{array}{l}\text { - An undischarged bankrupt; } \\
\text { - Charge for criminal offence relating to dishonesty or fraud; or } \\
\text { - Under any law relating to prevention of crime, drug trafficking or } \\
\text { immigration. }\end{array}$ \\
\hline $\begin{array}{l}\text { Conflict } \\
\text { Interest }\end{array}$ & $\begin{array}{l}\text { SC member or his/her immediate family: } \\
\text { - Not an executive or within the last two years of his/her proposed } \\
\text { appointment of the IFI; } \\
\text { - Not a substantial shareholder, executive director or senior officer of } \\
\text { the IFI or any of its affiliates; or } \\
\text { - Not have a significant business or other contractual relationship with } \\
\text { the IFI or any of its affiliates within the last two years. }\end{array}$ \\
\hline
\end{tabular}

Source: BNM (2019)

Based on the above Table 3, any application for appointment, reappointment, termination, resigns and disqualified must be informed and get approval from the BNM. In addition, as the SC member, he/she cannot serve the same IFI for more than nine years. Besides, the SC member is also must not have clash in time commitments that can affect his/her capability to discharge his/her duties effectively, not accept for more than one appointment either in Islamic bank, takaful operator or other prescribed institution and be an active politician. 
Moreover, the BOD is encouraged to appoint a SC member as a BOD member, developing a suitable succession planning for the SC and also developing a tight process for the appointment, reappointment and cessation of the SC members.

In term of the SC composition, IFIs must ensure that the $\mathrm{SC}$ is consists of by at least five members, the SC must be of a sufficient size and majority of the SC members and the chairman of the SC are shariah qualified person. Meanwhile, the secretariat to the SC must be able to coordinate, communicate and disseminate information among the SC, the BOD and senior management, conducting in-depth research and studies on shariah issues, providing day to day shariah advice and consultancy to relevant parties, proper distribution of shariah decisions or advice within the IFI and responsible on the administrative and secretarial functions to support the SC.

The third section outlines the responsibilities of the senior management on shariah governance. This include such as develop a sound management structure and reporting arrangement, implement shariah governance policies, procedures and practices, implement the rulings, decisions and advice of the SAC and the SC, support a sound understanding of shariah matters by conducting an effective communication policy, evaluate the operational support's quality to the SC on regular basis and report any potential or actual shariah non-compliance events to the BOD and the SC. Besides, senior management is also required to continuously update themselves with Islamic finance knowledge.

Fourth, under control functions, it focused on the effective management of shariah non-compliance risk by shariah risk management, shariah review and shariah audit on ongoing basis. Basically, IFI must ensure that the overall of shariah non-compliance risk management is structured, provide sufficient resources for the control functions and they must have direct access and without being worried to the SC. Besides, they are also must independent and have access to every potential shariah non-compliance risk in all business lines. In term of functions for each control function, the following Table 4 summarized the necessary functions that need to be performed by each function under shariah governance.

Table 4. Functions of Control Functions under Shariah Governance by SG 2019

\begin{tabular}{|c|c|}
\hline $\begin{array}{l}\text { Control } \\
\text { Functions }\end{array}$ & Functions \\
\hline $\begin{array}{l}\text { Shariah Risk } \\
\text { Management }\end{array}$ & $\begin{array}{l}\text { - To integrate between shariah non-compliance risk with conventional } \\
\text { risk management; } \\
\text { - To identify potential shariah non-compliance risk exposures; } \\
\text { - Assess and measure potential impact of shariah non-compliance risk } \\
\text { exposures; } \\
\text { - To develop appropriate risk mitigation measures; } \\
\text { - To closely monitor on both shariah non-compliance risk exposures }\end{array}$ \\
\hline
\end{tabular}




\begin{tabular}{|c|c|}
\hline & $\begin{array}{l}\text { and effectiveness of the risk mitigation measures; } \\
\text { - To report to the BOD, the SC and senior management on the shariah } \\
\text { non-compliance risk exposures; and } \\
\text { - To develop constructive decisions that may give escalate to shariah } \\
\text { non-compliance risks. }\end{array}$ \\
\hline $\begin{array}{l}\text { Shariah } \\
\text { Review }\end{array}$ & $\begin{array}{l}\text { - To identify, assess and monitor on shariah compliance by the IFI; } \\
\text { - To report on regular basis on shariah non-compliance issues and } \\
\text { findings to the BOD, the SC and senior management; } \\
\text { - To inform and provide the latest updates on regulatory requirements } \\
\text { especially SAC rulings to the BOD, the SC and senior management; and } \\
\text { - To ensure IFI's officers were provided with adequate training and } \\
\text { guidance on relevant shariah requirements. }\end{array}$ \\
\hline Shariah Audit & $\begin{array}{l}\text { - To assess the risk profile and each auditable area exposures by } \\
\text { developing a strong audit methodology; } \\
\text { - To develop a comprehensive shariah audit plan for shariah audit } \\
\text { process; } \\
\text { - To provide guidance on gathering information, auditing procedures } \\
\text { and audit assessment by developing a clear documented shariah audit } \\
\text { programs; and } \\
\text { - To communicate the audit findings, recommendations for } \\
\text { rectification measures and auditee's responses and action plans to the } \\
\text { BOD and the SC through an audit report. }\end{array}$ \\
\hline
\end{tabular}

Source: BNM (2019)

Fifth, under shariah compliance culture and remuneration, effective implementation of shariah governance can be obtained by ensuring effective communication policy is in place by the BOD. Besides, shariah compliance reinforce a risk culture in IFIs can be attained through adequate remuneration policy and performance measures by senior management, which is in line with the objective of shariah governance.

Last but not least, under transparency and disclosures, it is required for IFIs to disclose its shariah governance policies and practices information in the annual report. In this case, the BOD is responsible to disclose on its duties in monitoring the shariah governance implementation and also IFI's compliance with shariah in overall. Meanwhile, the SC is responsible to disclose their responsibilities on shariah governance and opinion on the level of shariah compliance by IFI. In the SC's disclosure, it also addresses the material shariah 
non-compliance events including its nature, status and measures undertaken. Such disclosure made by the SC must be signed by not less than two SC members. Besides, opinion made by the SC must be based on the written policy endorsed by the SC and approved by the BOD.

\section{Research Methodology}

This study applied a comprehensive analysis on three shariah governance guidelines in Malaysia under BNM which are: (i) Shariah Governance Framework (SGF) 2010; (ii) Islamic Financial Services Act (IFSA) 2013; and (iii) Shariah Governance Policy Document (SGPD) 2019. In applying the critical comparison between these shariah governance guidelines, several themes under shariah governance are identified to be used including the definition, objectives, structure, responsibility of key organs, control functions, independence, competency, confidentiality, consistency, appointment, cessation and disqualification, composition, meetings, remuneration, shariah compliance culture, transparency and disclosures and allocation of punishment. These themes will be used in comparative analysis made for this study.

\section{Comparative Analysis among SGF 2010, IFSA 2013 and SGPD 2019}

Based comparative analysis conducted among three shariah governance frameworks in Malaysia, namely: (i) SGF 2010, IFSA 2013 and SFPD 2019, the following Table 5 summarized the comparative analysis findings as follow.

Table 5. Functions of Control Functions under Shariah Governance by SG 2019

\begin{tabular}{|c|c|c|c|}
\hline Discussion & SGF 2010 & IFSA 2013 & SGPD 2019 \\
\hline $\begin{array}{l}\text { Definition of } \\
\text { shariah } \\
\text { governance }\end{array}$ & Not provided & Not provided & Not provided \\
\hline $\begin{array}{l}\text { Objectives of } \\
\text { shariah } \\
\text { governance }\end{array}$ & Discussed & Not provided & Not provided \\
\hline $\begin{array}{l}\text { Structure of } \\
\text { shariah } \\
\text { governance }\end{array}$ & $\begin{array}{l}\text { Discussed - limited } \\
\text { within IFI only (Tier } \\
\text { 1) }\end{array}$ & Not provided & $\begin{array}{l}\text { Discussed }- \text { within IFI } \\
\text { and IFI to BNM (Tier } 1 \& \\
\text { 2) }\end{array}$ \\
\hline $\begin{array}{l}\text { Responsibility } \\
\text { of the BOD for } \\
\text { shariah } \\
\text { governance }\end{array}$ & Discussed & Not provided & $\begin{array}{l}\text { Discussed - including on } \\
\text { continuous development } \\
\text { of the BOD on shariah } \\
\text { knowledge }\end{array}$ \\
\hline Responsibility & Discussed & Discussed & Discussed \\
\hline
\end{tabular}




\begin{tabular}{|c|c|c|c|}
\hline of the SC & & & \\
\hline $\begin{array}{l}\text { Responsibility } \\
\text { of the } \\
\text { management } \\
\text { for shariah } \\
\text { governance }\end{array}$ & Discussed & Not provided & $\begin{array}{l}\text { Discussed - including on } \\
\text { continuous development } \\
\text { of the management on } \\
\text { shariah knowledge }\end{array}$ \\
\hline $\begin{array}{l}\text { Control } \\
\text { functions for } \\
\text { shariah } \\
\text { governance }\end{array}$ & $\begin{array}{l}\text { - Shariah review } \\
\text { - Shariah audit } \\
\text { - Shariah risk } \\
\text { management } \\
\text { - Shariah } \\
\text { research }\end{array}$ & $\begin{array}{l}\text { Shariah audit by BNM } \\
\text { (Tier 2) }\end{array}$ & $\begin{array}{l}\text { - Shariah review } \\
\text { - Shariah audit } \\
\text { - Shariah risk } \\
\text { management } \\
\text { - Shariah research } \\
\text { function merged with the } \\
\text { secretariat to the SC - not } \\
\text { classified under control } \\
\text { functions }\end{array}$ \\
\hline $\begin{array}{l}\text { Independence } \\
\text { of SC }\end{array}$ & Discussed & Not provided & Discussed \\
\hline $\begin{array}{l}\text { Competency of } \\
\text { SC }\end{array}$ & Discussed & Not provided & Discussed \\
\hline $\begin{array}{l}\text { Confidentiality } \\
\text { of SC }\end{array}$ & Discussed & Discussed & Discussed \\
\hline $\begin{array}{l}\text { Consistency of } \\
\text { SC }\end{array}$ & Discussed & Not provided & Discussed \\
\hline $\begin{array}{l}\text { Appointment, } \\
\text { cessation \& } \\
\text { disqualification } \\
\text { of SC }\end{array}$ & Discussed in general & Discussed in general & $\begin{array}{l}\text { Discussed in detail - } \\
\text { tenure not more than } 9 \\
\text { years in the same IFI, not } \\
\text { active in politics. }\end{array}$ \\
\hline $\begin{array}{l}\text { Composition of } \\
\text { SC }\end{array}$ & Discussed in general & Not provided & $\begin{array}{l}\text { Discussed in details - at } \\
\text { least } 5 \text { members }\end{array}$ \\
\hline SC Meetings & Discussed in general & Not provided & $\begin{array}{l}\text { Discussed in details - } \\
\text { concern on non-physical } \\
\text { meetings }\end{array}$ \\
\hline
\end{tabular}




\begin{tabular}{|c|c|c|c|}
\hline $\begin{array}{l}\text { Remuneration } \\
\text { of SC }\end{array}$ & Discussed & Not provided & Discussed \\
\hline $\begin{array}{l}\text { Shariah } \\
\text { compliance } \\
\text { culture }\end{array}$ & Discussed & Not provided & Discussed \\
\hline $\begin{array}{l}\text { Transparency } \\
\text { and disclosures }\end{array}$ & $\begin{array}{l}\text { Provide example of } \\
\text { minimum annual } \\
\text { disclosure } \\
\text { appendix }\end{array}$ & Not provided & $\begin{array}{l}\text { Discussed }- \text { report on } \\
\text { shariah governance } \\
\text { practices in annual report }\end{array}$ \\
\hline $\begin{array}{l}\text { Allocation for } \\
\text { punishment }\end{array}$ & Not provided & $\begin{array}{l}\text { Imprisonment for a } \\
\text { term not exceeding } \\
\text { eight years or to a } \\
\text { fine not exceeding } \\
\text { RM25 million or to } \\
\text { both }\end{array}$ & Not provided \\
\hline
\end{tabular}

Based on Table 5, the biggest loopholes for these three shariah governance guidelines is the absence of the definition of shariah governance itself. Besides, another important element which is shariah governance objectives is only discussed in SGF 2010. In term of shariah governance structure, both SGF 2010 and SGPD 2019 are discussed where SGF 2010 is focused on the IFI level, while SGPD 2019 have a broad coverage when it also included in details on the national level with the authority which is BNM.

Next, on the responsibility of the BOD of IFI, both SGF 2010 and SGPD 2019 are discussed, however, SGDP 2019 have more extensive discussion as it also include the needs for continuous development on the shariah knowledge. This is in line with the ultimate responsibility of shariah compliance, which is on the BOD responsibility. Similarly, on the responsibility of the management, both SGF 2010 and SGPD 2019 are discussing the content with SGDP 2019 have the same extensive discussion and also proposing the needs for the management to have continuous development on the shariah knowledge. Meanwhile, on the responsibility of the SC, all three shariah governance frameworks are well discussed.

On control functions of shariah governance, SGF 2010 proposes four types of control functions which are: (i) shariah review; shariah audit; (iii) shariah risk management; and (iv) shariah research. However, in SGDP 2019, these control functions becoming only three types where shariah research function is combine with the secretariat to the SC function and no longer classified under control function. In IFSA 2013, the discussion on the is focused on the shariah audit but it is not referred to the IFI level but instead it refers to the national level or second tier, which is the responsibility of the BNM to have such shariah audit on IFIs in Malaysia. 
In term of independence, competency, confidentiality and consistency of the SC, both SGF 2010 and SGPD 2019 are discussing on these matters except for IFSA 2013, which only covering on the confidentiality of the SC on information accessed in order for them to make decision. In term of the appointment, cessation and disqualification of the SC, SGPD 2019 provide in-depth guideline as compared to SGF 2010 including by introduction of the tenure of the SC which not exceed nine years in an IFI, and also not to be involved actively in politics. For composition of the SC, both SGF 2010 and SGPD 2019 are covering this aspect where SGPD 2019 provides a new requirement where SC must be consist of at least five members. Similarly, under SC meeting, SGPD 2019 also have additional concerns on the non-physical meetings and urges for IFI to ensure this kind of meeting do not downgraded the effort and commitment of the SC members in fulfilling their obligations as compared to SGF 2010. On the other hand, IFSA 2013 only covering in general on the appointment, cessation and disqualification of the SC as stated in the Section 33 and 34. For remuneration of the SC, both SGF 2010 and SGPD 2019 provide the discussion, while there is no discussion on this matter under IFSA 2013.

For shariah compliance culture, both SGF 2010 and SGPD 2019 are discussed while IFSA 2013 does not touch on this aspect. Meanwhile, for transparency and disclosures aspect, previous SGF 2010 only provide the example of the minimum annual disclosure in the appendix, while SGPD 2019 have more extensive discussion especially on the report of shariah governance practices in the IFI annual report. Last but not least, on the allocation of punishment for the breach of the duties, only IFSA 2013 have such provision where breach on the shariah governance is subjected to imprisonment for a term not exceeding eight years or to a fine not exceeding RM25 million or to both.

\section{Conclusion}

This paper discusses the important role of shariah governance guidelines in the Islamic finance industry to ensure that the whole activities of financing activities are in line with the shariah. Comparative analysis on the shariah governance guidelines issued by BNM, which consist of SGF 2010, IFSA 2013 and SGPD 2019 are provided and discussed.

In short, all these three guidelines still can be concluded are not comprehensive enough, especially on the definition and objectives of shariah governance. Perhaps in the future, it is suggested to include these two important aspects in shariah governance guidelines. However, other aspects on shariah governance are well covered especially by SGPD 2019. Thus, it can be concluded that SGPD 2019 is the most comprehensive guideline for shariah governance as compared to SGF 2010 and IFSA 2013. Another suggestion is to cover in-depth on both first and second tier of shariah governance in the future amendment shariah governance guidelines. It is expected that the highlights in this research will be the interests of regulators and industrial players for future development in the said guidelines.

The growth of Islamic based organizations especially in Malaysia practices cannot be taken lightly. IFIs can lead not only to serves shareholders wealth, but it also can be as a key player in economic and social growth and development. As for that, shariah governance being demanded and its existence are highly significant especially for society overall. The 
challenges for IFIs should be taken seriously. It is because the failure of IFIs would have an impact on the economy and image of Islam. Thus, further studies should be carried out on how to strengthen IFIs governance and their impact on the society at large.

\section{Acknowledgement}

The authors would like to thank Universiti Sains Islam Malaysia for the financial assistance from a research grant under the title of Shariah Audit, Governance and Risk Management in Islamic Financial Institutions (USIM/UNISSA/MG/FEM/052002/70118), which funded this paper.

\section{References}

Abdul Rahman, A. R. (2010). Sha'riah Audit for Islamic Financial Services: The Needs and Challenges. The Journal of Muamalat and Islamic Finance Research, 7(1), 133-146.

Abdul Rahman, M. Z. (2015). Aplikasi Maqasid Al-Syari'ah Dalam Pentadbiran Negara: Satu Tinjauan Sejarah Islam. Jurnal Fiqh, 12, 29-56.

Abdullah Saif Alnasser, S., \& Muhammed, J. (2012). Introduction to Corporate Governance from Islamic Perspective. Humanomics, 28(3), 220-231. https://doi.org/10.1108/ 08288661211258110

Abozaid, A., \& Dusuki, A. W. (2007). The Challenges of Realizing Maqasid al-Shariah in Islamic Banking and Finance. International Journal of Economics, Management and Accounting, 15(2), 143-165.

BNM. (2010). Shariah Governance Framework for Islamic Financial Institutions. Bank Negara Malaysia (BNM). Kuala Lumpur: BNM. [Online] Available: https://www.bnm.gov. my/guidelines/05_shariah/02_Shariah_Governance_Framework_20101026.pdf（September $25,2019)$.

BNM. (2013a). Guidelines on Corporate Governance for Licensed Institutions. Bank Negara Malaysia (BNM). Kuala Lumpur: BNM. [Online] Available: http://www.bnm.gov.my/ guidelines/01_banking/04_prudential_stds/16_corporate_governance.pdf (September 25, 2019).

BNM. (2013b). Islamic Financial Services Act 2013. Bank Negara Malaysia (BNM). Kuala Lumpur: BNM. [Online] Available: http://www.bnm.gov.my/documents/act/en_ifsa.pdf (September 25, 2019).

BNM. (2019). Shariah Governance Policy Document. Bank Negara Malaysia (BNM). Kuala Lumpur: BNM. [Online] Available: http://www.bnm.gov.my/index.php?ch=57\&pg=140\&ac= $835 \& b b=$ file (September 25, 2019).

Cadbury, A. (1992). Report of the Committee on the Financial Aspects of Corporate Governance. London, United Kingdom: Gee \& Co. Ltd.

Chapra, M. U., \& Ahmed, H. (2002). Corporate Governance in Islamic Financial Institutions. Occasional Paper (No. 93). Jeddah: The Islamic Research and Teaching Institute (IRTI). 


\section{Macrothink}

Journal of Public Administration and Governance ISSN 2161-7104 2020, Vol. 10, No. 1

CIBAFI, CIMB Islamic., \& Thomson Reuters. (2015). Malaysia Islamic Finance Report 2015. Kuala Lumpur: General Council for Islamic Banks and Financial Institutions (CIBAFI), CIMB Islamic Bank Berhad and Thomson Reuters. [Online] Available: http:www.irti.org/ English/News/Documents/406.pdf (November 25, 2017).

Ernst \& Young. (2016). World Islamic Banking Competitiveness Report 2016. [Online] Available: http://www.ey.com/Publication/vwLUAssets/eyworld-islamic-banking-competitive ness-report-2016/\$FILE/ey-worldislamic-banking-competitiveness-report-2016.pdf (June 20, 2017).

GIFR. (2016). Global Islamic Finance Report 2016. Global Islamic Finance Report (GIFR). Cambridge, United Kingdom: Cambridge Institute of Islamic Finance. [Online] Available: http://www.gifr.net/gifr_2016.htm (January 16, 2020)

Hanefah, M. M., \& Kamaruddin, M. I. H. (2019). Shariah Governance and Assurance in Islamic Financial Sectors. Negeri Sembilan: USIM Press.

Hasan, Z. (2009). Corporate Governance: Western and Islamic Perspectives. International Review of Business Research Papers, 5(1), 277-293.

Ibrahim, S. H. M. (2009). IFRS vs AAOIFI: The Clash of Standards?. MPRA Paper No. 12539. [Online] Available: http://mpra.ub.uni-muenchen.de/12539/1/MPRA_paper_12539. pdf (June 20, 2017).

IFSB. (2009). IFSB-10: Guiding Principles on Shari'ah Governance Systems for Institutions Offering Islamic Financial Services. Islamic Financial Services Board (IFSB). [Online] Available: http://www.ifsb.org/standard/IFSB10\%20Shariah\%20Governance.pdf (September 7, 2017).

Kamaruddin, M. I. H., \& Hanefah, M. M. (2017). Enhancing Shariah Audit Practices in Islamic Financial Institutions in Malaysia. Journal of Modern Accounting and Auditing, 13(11), 457-470. https://doi.org/10.17265/1548-6583/2017.11.001

Kasim, N., NuHtay, M. S. N., \& Salman, S. A. (2013). Shariah Governance for Islamic Capital Market: A Step Forward. International Journal of Educational Research, 1(6), 1-14.

Khan, M. M., \& Bhatti, M. I. (2008). Islamic Banking and Finance: On its Way to Globalization. Managerial Finance, 34(10), 708-725. https://doi.org/10.1108/03074350810 891029

Khiyar, K. A. (2012). Malaysia: 30 Years of Islamic Banking Experience (1983-2012). International Business \& Economics Research Journal, 11(10), 1133-1146. https://doi.org/ 10.19030/iber.v11i10.7259

Lewis, M. K. (2005). Islamic Corporate Governance. Review of Islamic Economics, 9(1), 5-29.

Miskam, S., \& Nasrul, M. A. (2013). Shariah Governance in Islamic Finance: The effects of the Islamic Financial Services Act 2013. In Proceedings of World Conference on Integration 


\section{Macrothink}

of Knowledge, November 25-26, Malaysia: Langkawi.

Nathan Garas, S., \& Pierce, C. (2010). Shari'a Supervision of Islamic Financial Institutions. Journal of Financial Regulation and Compliance, 18(4), 386-407. https://doi. org/10.1108/13581981011093695

OECD. (2014). Risk Management and Corporate Governance 2014. Organisation for Economic Cooperation and Development (OECD). Paris: OECD Publications. [Online] Available: $\quad$ http://www.oecd.org/daf/ca/risk-management-corporate-governance.pdf (November 25, 2017).

SC. (2017). Malaysian Code on Corporate Governance 2017 (MCCG 2017). Securities Commission of Malaysia (SC). Kuala Lumpur: SC. [Online] Available: https://www.sc.com. my/wp-content/uploads/eng/html/cg/mccg 2017.pdf (November 25, 2017).

Shafii, Z., Salleh, S., Hanefah, M. M., \& Jusoff, K. (2013). Human Capital Development in Shariah Audit. Middle-East Journal of Scientific Research, 13, 28-34. https://doi.org/ 10.5829/idosi.mejsr.2013.13.1878

Shafii, Z., Salleh, S., \& Shahwan, S. H. (2010). Management of Shariah Non-Compliance Audit Risk in the Islamic Financial Institutions via the Development of Shariah Compliance Audit Framework and Shariah Audit Programme. Kyoto Bulletin of Islamic Area Studies, 3(2), 3-16.

\section{Copyright Disclaimer}

Copyright for this article is retained by the author(s), with first publication rights granted to the journal.

This is an open-access article distributed under the terms and conditions of the Creative Commons Attribution license (http://creativecommons.org/licenses/by/4.0/). 